\title{
Risk Management of Granola Potato Seeds Production: A Study in Kertasari, West Java, Indonesia
}

\author{
Eliana Wulandari*, Ernah, Hepi Hapsari and Amelia Hendra \\ Department of Agricultural Social Economics, Faculty of Agriculture, \\ Universitas Padjadjaran, Bandung, Indonesia \\ *Corresponding author: eliana.wulandari@unpad.ac.id
}

\begin{abstract}
The quality of potato seeds is important to support increased production. The majority of farmers do not certify potato seeds, which can result in various risks for potato seed production activities. This research aims to identify the risks of potato seed production and formulate risk control strategies for potato seeds production. The research uses house of risk method. The results of this study show thirty-nine identified risk events. The most impactful risk event was rotten potato. Thirty-two identified risk agents with two priorities must be handled first. The most effective ways in handling strategy are training, the certification of potato seed breeder farmers, potato seed certification, as well as purchasing breeder seeds from vegetable crop research center and from other seed breeders. This research suggests the needs to produce quality potato seeds by certifying potato seed and to update the competency certification of potato seed breeders.
\end{abstract}

Keywords: house of risk (HOR); potato seeds; production risk; risk management

Cite this as: Wulandari, E., Ernah, Hapsari, H., \& Hendra, A. (2021). Risk Management of Granola Potato Seeds Production: A Study in Kertasari, West Java, Indonesia. Caraka Tani: Journal of Sustainable Agriculture, 36(2), 308-318. doi: http://dx.doi.org/10.20961/carakatani.v36i2.38860

\section{INTRODUCTION}

Agricultural sector has a major contribution to Indonesia, especially in providing employment for the Indonesian population (Widyawati, 2017). One of the supporting factors for increasing production is the use of qualified seeds through a certification as one of the efforts to develop sustainable agriculture in Indonesia. Certification reflects the quality of seeds, which are expected to ensure high productivity leading to increasing national food production (Eljai et al., 2017).

Seed treatment has an important role in sustainable agricultural production through protection from insects and diseases to increase yields (Sharma et al., 2015). Lack of awareness about seed treatment is a limiting factor in managing disease (Sharma et al., 2015). To solve the problem in a sustainable seed supply system, a collaboration is required to be developed among farmers, researchers, agro-enterprise specialists, NGOs and the formal seed industry (David, 2004).

Potato is one of agricultural products contributing to the fulfillment of the carbohydrate needs of the human diet (King and Slavin, 2013) and have important role as substitute for staple food (Zhang et al., 2017; Sawicka et al., 2018; Gao et al., 2019). In addition, potato contains mineral, protein, vitamins and others benefits (Love and Pavek, 2008; Burlingame et al., 2009; Tian et al., 2016), as well as phytochemicals as bioactive components (Ezekiel et al., 2013), which act as antioxidants in the prevention of many chronic diseases (McGill et al., 2013; Williams et al., 2013).

\footnotetext{
* Received for publication January 11, 2020

Accepted after corrections April 10, 2021
} 
Potato production in Indonesia fluctuated during the 2015-2019 period, in which the production reached 1,314,657.00 tons in 2019 (BPS-Statistics Indonesia, 2019). The potato production fluctuation was caused by many challenges in developing potatoes, including competing with other horticulture commodities and land conservation for other purposes (Rogi et al., 2016). Compared to other potato producing countries in Asia, Indonesia's potato productivity was still low particularly in 2019 , which reached 19.07 tons per hectare (Ministry of Agriculture, 2020). Potato productivity in other country such as in India reached 22.30 tons per ha. Despite having a nearly identical climate to the country, Indonesia's potato productivity is still lower (Jella et al., 2017). The low productivity of potatoes in Indonesia was caused by several factors, such as farmers' habits planting potato in all the whole parts of land (Yusianto et al., 2020), using low quality seeds, lack of knowledge about technical culture, continuous planting and limited capital of farmers (Sunaryono, 2007).

Data from the Directorate General of Horticulture in 2008 reported that the availability of new certified seeds was only $8.3 \%$ of the national seed demand or 8,066 tons of 96,277 tons (Mulyono et al., 2017). Lack of availability of quality and certified seed is one of the causes of low productivity of potato (Jufri et al., 2015).

Potato seeds commonly used in developing countries are fourth or newer generation seeds. For example in Bangladesh, the seeds used by farmers are eighth-generation seeds, which have been reproduced by the government six times and by cultivators twice (Ilangantileke et al., 2001). The seeds commonly used by potato farmers in Indonesia are the fourth-generation. The newer the generation of potatoes used, the greater the likelihood of quality degradation to occur (Mulyono et al., 2017).

Regarding the data of Central Bureau of Statistics (BPS-Statistics Indonesia, 2019), West Java produced large quantities of potato with an average production of 267,042 tons in the 2015-2019 period. One of the centers of potato production in West Java is Bandung Regency, which produces 5,061 tons of potatoes, equivalent to $38 \%$ of production in West Java. Kertasari Sub-district is one of the potato producers in Bandung Regency, with an altitude between 1,200-1,800 $\mathrm{m}$ above sea level, meeting the requirements for growing potato plants, which are suitable to grow at an altitude of 1,000-3,000 $\mathrm{m}$ above sea level (Samadi, 2007).

To fulfil its market needs, Kertasari produces not only potatoes but also potatoes seeds. The training program for potato seed production has been provided by the government and Japan International Cooperation Agency (JICA) to ten farmers in Kertasari since 1982. Potato seed production training has been provided to the farmers in Kertasari for four times. After attending the training, farmers are equipped with field education and assistance from food and horticulture crop seed supervision and certification center (Balai Pengawasan dan Sertifikasi Benih Tanaman Pangan dan Hortikultura-BPSBTPH) for one year. The training program has made Kertasari as one of the potato seed producing regions in Bandung Regency. However, after farmers were considered capable of implement the potato production activities independently without supervision, JICA's supervision was stopped. However, after the supervision termination, it seems that most of the farmers forgot the importance of potato seed certification.

Breeding activities in Kertasari have supported the Bandung Regency Government's agricultural or plantation production improvement program. However, seed fulfilment efforts carried out by breeder farmers were not simple to implement. The potato seed certification process performed by the farmers in Kertasari was terminated because of the lack of capital (Hendra and Wulandari, 2020). According to farmers, the yield of the seeds to be certified was charged a fee of IDR 25 per $\mathrm{kg}$ for G2 seeds, so if farmers want to label 10 tons of seeds, the cost is difficult to afford. The cost is getting more difficult to afford if the farmers want to label G0 and G1 seeds because they have to spend IDR 5,000 and IDR 3,000 per knol, respectively (per potato seed).

Potato breeder farmers also faced challenges from pests and diseases. During the breeding period, the potato seeds could be attacked by Phthorimae operculella (Rondon, 2010), which might cause a loss of up to $25 \%$ of production yield. The attack of Ralstonia solanacearum caused the tuber to rot (Mansfield et al., 2012), while the strike of the Pseudomonas solanacearum bacteria could cause a loss as 
many as 10-20 yields from 1000 seeds (Gunawan, 2006; Setiawan, 2019). Challenges may also arise from plantlets with regard to temperature and humidity of the plantlets (Kozai et al., 1997). Transfer process of plantlets needs to be done carefully in sterile conditions, for tools, materials and farmers to avoid the possibility of failure in breeding.

Those challenges provide the possibility of failure of the breeding process, which may affect production. Therefore, the management of each risk is required to be done to prevent worse impact (Musta'inah et al., 2017). This also needs to be done to minimize the possibility of losses. The training on potato seed breeding was given by the government, but breeder farmers still encountered production risks. Therefore, risk management strategies must be developed in order to reduce losses. The research of potato production risk in Kertasari is significant since the risk analysis of potato production has not been conducted in Kertasari as the important area for potato production. This research aims to analyze the risks of potato seed production and formulate risk control strategies for potato seed production.

\section{MATERIALS AND METHOD}

This study was conducted from June to November 2019, involving 10 potato breeder farmers in Kertasari as the entire population of this study. The object examined in this research was the risk of potato seed production. Kertasari was selected as the study area considering that Kertasari is one of the centers of potato production and potato seed breeding in Bandung Regency, West Java Province, Indonesia. This study applied risk analysis method. Descriptive analysis was performed to identify the risks occurring in potato seed production and to formulate mitigation strategies in Kertasari. The risk analysis in this study was conducted by applying the House of Risk (HOR) model. HOR is a modified form of House of Quality model (Pujawan and Geraldin, 2009). There are two phases in the HOR, namely HOR 1 to determine the priority risk agents and HOR 2 to determine the priority of the most effective preventive measures.

\section{HOR 1}

There are several steps that are necessary to be carried out in HOR 1, namely identifying risks in each activity until finally risk events are obtained and assessing the severity of the impact of each risk event. The assessment is carried out by giving a value of 1 to 10 according to the severity of the impact caused where 10 is given for a risk event that has a harmful effect. The next step includes identifying risk agents and providing an assessment of the possibility of occurrence. Similar to the assessment of risk events, an assessment for risk agents is also performed by giving a value of 1 to 10 according to the level of probability of occurrence. The smaller the given value means the risk agent almost never happens. After an assessment is completed, a correlation matrix between the risk agent and the risk event is made. Each column in the correlation matrix is given a value $\{0$, $1,3,9\}$, where 0 (zero) shows no correlation while 1, 3 and 9 show low, medium and high correlation levels, respectively. The final step in HOR 1 is calculating the ARPj value for each risk agent and ranking the highest ARPj value to the lowest. ARPj calculations use the following formula:

$$
A R P_{j}=O_{j} \sum S_{i} R_{i j}
$$

where:

$$
\begin{aligned}
\mathrm{ARP}= & \text { Aggregate risk potential } \\
\mathrm{S}= & \text { Severity of risk event } \\
\mathrm{R}= & \text { Relationship between risk agent and risk } \\
& \text { event }
\end{aligned}
$$

\section{HOR 2}

After obtaining the rank of ARPj value for each risk agent, the steps in HOR is carried out. The first step in HOR 2 is determining the priority risk agent by using the Pareto diagram. The application of the Pareto law to risk is that $80 \%$ of loss is caused by only $20 \%$ of the crucial risk. If $20 \%$ of this crucial risk can be managed, the company can avoid $80 \%$ of the loss (Kountur, 2008). After obtaining a priority risk agent, a relevant preventive action (PA) is prepared to handle the risk agent and a correlation matrix between risk agent and preventive action is made. Each column in the correlation matrix is given a value $\{0,1,3,9\}$, where 0 (zero) shows no correlation while 1, 3 and 9 show low, medium and high correlation levels, respectively. Each PA has the value of total effectiveness $\left(\mathrm{TE}_{\mathrm{k}}\right)$ which is calculated by the formula:

$$
\mathrm{TE}_{\mathrm{k}}=\sum_{\mathrm{j}} \mathrm{ARP}_{\mathrm{j}} \times \mathrm{E}_{\mathrm{jk}} \ldots
$$


where:

$\mathrm{TE}=$ Total effectiveness

$\mathrm{ARP}=$ Aggregate risk potential

$\mathrm{E} \quad=$ Relationship between mitigation event and risk agent

Next, an assessment of degree of certification $\left(D_{k}\right)$ is carried out. The $D_{k}$ value is represented by the number $\{3,4,5\}$ in accordance with the difficulty level of applying the preventive action. The higher the $D_{k}$ value, the more difficult preventive action to be realized and vice versa. The final step is calculating the effectiveness to certification $\left(\mathrm{ETD}_{\mathrm{k}}\right)$ for each preventive action and sort it from the highest to lowest. ETD $_{\mathrm{k}}$ can be calculated using the formula below:

$$
\mathrm{ETD}_{\mathrm{k}}=\frac{\mathrm{TE}_{\mathrm{k}}}{\mathrm{D}_{\mathrm{k}}}
$$

where:

ETDk $=$ Effectiveness to certification

$\mathrm{TE}_{\mathrm{k}}=$ Total effectiveness

$\mathrm{D}_{\mathrm{k}} \quad=$ Degree of certification

\section{RESULTS AND DISCUSSION}

The research of potato production risk in Kertasari is vital, in which Kertasari is the important area for potato production. Therefore, the risk analysis of potato seed production and the formulation of risk control strategies for potato seed production are necessary to be performed in this study. Topographically, Kertasari has a mountainous terrain with highlands and hills. The majority of the land in Kertasari is used for agriculture, including potato cultivation. Farmers in Kertasari had the same technical basis for potato seed propagation because they participated in joint training. Each adjustment resulted in only a few technical differences in seed propagation among farmers.

\section{HOR 1}

In the process of potato seed production carried out by farmers in Kertasari, 39 risk events were identified. These risk events could be identified by discussions and interviews with farmers producing potato seeds. All the risks of potato seed production are presented in Table 1 .

Table 1. List of risk events of potato seed production

\begin{tabular}{llc}
\hline Cultivation stages & \multicolumn{1}{c}{ Risk event } & Severity \\
\hline Pre-planting & Contamination of pests and/or diseases from neighboring & 6.0 \\
& farming & 6.0 \\
& Unguaranteed quality of seed & 7.0 \\
& Lack of watering & 7.0 \\
& Increase in the production costs & 6.0 \\
\hline Irregular drainage channels & 4.7 \\
& Plants do not grow & 3.0 \\
& Plants grow slowly & 4.0 \\
\hline Caring & Prop spacing is not as recommended & 8.0 \\
& Plants attacked by light-blight disease & 7.3 \\
& Plants that do not grow well & 7.0 \\
& Plants attacked by viruses & 9.0 \\
& Plants attacked by Fusarium sp. & 7.8 \\
& Plants attacked by Liriomyzahuidobrensis & 6.0 \\
Uncontrolled pest & 8.0 \\
& Lack of pesticide & 8.0 \\
Increased attack of pest & 7.0 \\
Dead plants & 8.5 \\
Flooded plants & 8.0 \\
Attack of Phthorimaeoperculella & 3.0 \\
Unidentified virus attacks & 8.0 \\
Attack of Ralstonia solanacearum & 9.0 \\
Attack of pests and diseases & 7.0 \\
Plant overdose on pesticides & 7.0 \\
\hline
\end{tabular}




\begin{tabular}{llc}
\hline Cultivation stages & \multicolumn{1}{c}{ Risk event } & Severity \\
\hline Harvesting & Rotten harvested potatoes & 9.3 \\
& Hollowed harvested potatoes & 8.3 \\
& Elongated potato forms & 3.0 \\
& Riven harvested potatoes & 5.0 \\
& Harvested potatoes attacked by scab & 8.0 \\
& Stolen crop & 5.0 \\
& Late harvested plants & 8.0 \\
& Peeled off tuber skin is peeling & 8.0 \\
\hline Post-harvesting & Seeds attacked by Phthorimae operculella & 8.3 \\
and storing & Seeds attacked by dry-rot disease & 9.0 \\
& Rotten seeds & 8.5 \\
& Seeds suffering physical damage & 8.0 \\
& White sprouts & 6.0 \\
\hline Packing & Peeled of seed skin & 2.0 \\
& Rotten packaged seeds & 8.0 \\
\hline
\end{tabular}

Table 1 presents that the greatest impact faced by the farmers in potato seed production was the rotten potato, with the value of 9.3. The rot of potato bulbs when harvested can be caused by several factors, one of which is weather. Potato plants require a lot of water but are very sensitive to standing water. Therefore, the drainage must be properly designed so that there is no puddle of water in the field of planting potato seeds. Potato must be harvested when the weather is sunny and does not rain (Pitojo, 2004).

Besides the rotten potato, the high impact of potato seed production were plants attacked by viruses, plants attacked by Ralstonia solanacearum and seeds attacked by dry-rot disease. One of the preventive strategies that can be made to avoid virus attack on potato plants is by isolating potato seeding fields from the surrounding land (Ministry of Agriculture, 2014). However, the farmers did not isolate the land due to the limited land. The disease caused by Ralstonia solanacearum can be threatened by crop rotation (Mwaniki et al., 2017). However, the farmers did not apply crop rotation because of land scarcity.

Each identified risk event has its own root cause. Therefore, the identification of risk sources or risk agents is also required to be performed. Discussions and interviews with farmers have helped identify risk agent that occurred in potato seed production in Kertasari. The risk agents are presented in Table 2.

Table 2. List of risk agents of potato seed production

\begin{tabular}{llc}
\hline \multicolumn{1}{c}{ Risk source categories } & \multicolumn{1}{c}{ Risk agent } & Occurrence \\
\hline Climate and weather & Unpredictable seasonal changes & 6.2 \\
& Flood & 0.0 \\
\hline Pest and disease & Plants attacked by Thrips & 8.0 \\
& Plants attacked by Gryllotalpa sp. & 8.0 \\
& Plants attacked by Phthorimaeoperculella & 8.0 \\
\hline Labor & Planting rotation on breeding area that was not done & 8.0 \\
& Untidy arrangement of plants & 2.0 \\
& Not sterile planting media & 2.0 \\
& No lime provided & 3.0 \\
& No Furadan given & 1.5 \\
& Position of sprouts when planting that was not facing up & 6.0 \\
& Late watering & 5.0 \\
\hline Labor & Inaccurate disease analysis & 2.3 \\
& Delay or non-application of pesticides & 3.5 \\
& Excessive use of pesticides & 1.0 \\
\hline
\end{tabular}




\begin{tabular}{llc}
\hline Risk source categories & \multicolumn{1}{c}{ Risk agent } & Occurrence \\
\hline & Not installed stake & 2.5 \\
& Lack of supervision ahead of harvest & 6.0 \\
& Prematurely harvested plants & 2.0 \\
& Harvest done when raining & 4.5 \\
& Careful sorting the crops & 2.5 \\
& The seeds kept in wet & 2.0 \\
& Seeds stacked too high & 4.0 \\
& Storage without closing & 2.0 \\
& Lack of supervision of workers & 6.0 \\
& Inadvertently work & 4.3 \\
\hline Unfavorable market price & 5.0 \\
& The storage warehouse temperature that was too hot or & 2.7 \\
& cold & \\
& Seeds without certificates & 9.0 \\
& Breeding area adjacent to the neighboring farming & 7.5 \\
Warehouse facilities that do not meet the standards & 8.0 \\
& Limited capital & 7.0 \\
The seed production process that was not supervised by & 7.0 \\
& BPSBTPH & \\
\hline
\end{tabular}

Table 2 demonstrates that the most frequently occurring risk agent that appears in potato seed production in Kertasari was seeds without a certificate, with a value of 9 , indicating that the incidence rate for the risk agent of seeds without a certificate is very high or very frequent. The access of quality seeds is crucial to improve food security (Abebe and Alemu, 2017). BPSBTPH requires seed producers to use certified (labelled) seeds in their breeding activities, but most the farmers did not meet those requirements.

According to the farmers, initially certified seeds were used and the seed certification process was carried out. This began when the seed breeding training in Kertasari accompanied seed certification supervised by BPSBTPH. However, after the training period was accomplished, only few farmers continued seed breeding and certification activities, while the rest did not carry out seed certification, in which was currently the case for almost all farmers. This was because the majority of the seeds were used for farming. The majority of the seeds produced were used for personal production and some were sold to other potato farmers. Farmers used seeds for personal production because the price of potato seeds on the market was expensive. Based on the information from potato seed farmers in Kertasari, planting potatoes required a large amount of capital, in which the price of one kilogram of second-generation seeds (G2) ranged from IDR 12,000 to IDR 25,000 per $\mathrm{kg}$.

Some farmers also traded their seeds to other farmers without labeling, including the trading for seeds outside their area. Farmers indirectly distributed unlabeled seeds of unknown quality to other farmers. Seed certification is essential for determining the quality of seeds (Muthuraj et al., 2017). The use of quality seeds can increase crop productivity (Roy, 2014). Furthermore, Eljai et al. (2017) confirmed that certified seeds can meet the market quality standards, guarantee high productivity and adapt to various biotic and abiotic stresses.

A correlation needs to be assessed for the identified risk event and agent. The severity and occurrence values obtained in the risk identification process were included in the HOR 1 model to obtain the ARP value. The ARP calculation results depict that the risk agent of the seed production process that is not supervised by BPSBTPH has the highest ARP value. This demonstrates that the unsupervised seed production process has the highest likelihood of occurrence and is a source of many risk events with severe consequences.

The production and certification process of potato seeds are integral parts (Ministry of Agriculture, 2014). The potato seed production process in Kertasari was not accompanied by 
seed certification so that it was not supervised by BPSBTPH. This allowed various risk events to occur.

\section{HOR 2}

In the previous phase, ARP values for each risk agent and the rank of risk agent according to the ARP value were obtained. In handling the risk agent, the order of managing risk agent was determined by the rank of ARP values. However, not all risks were treated in the same way. To determine the priority risk source that would receive handling focus, the pareto principle was used. Pareto principle is a simple technique that help decision makers identify the most significant problems that need to be addressed and resolved right away (Dermawan, 2006). The pareto principle, which has an 80:20 rule illustrates that $80 \%$ of losses come from $20 \%$ crucial risks and that by managing $20 \%$ of crucial risks, $80 \%$ of the losses can be avoided.

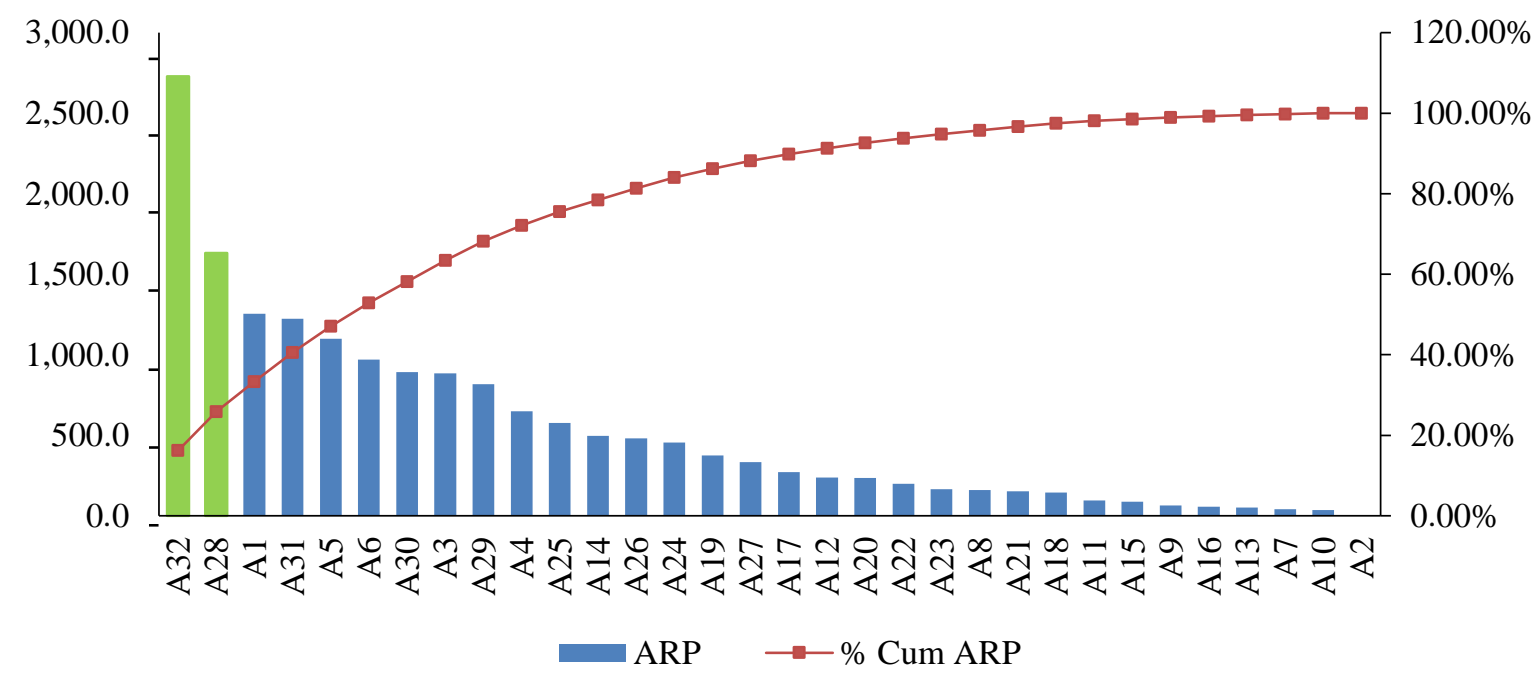

Figure 1. Pareto diagram of cumulative percent of ARP across all sources of risk

As presented in Figure 1, the priority risk source with the percent cumulative ARP value below $20 \%$ was the seed production process that was not supervised by BPSBTPH. Preventive actions (PA) were formulated for priority risk sources as detailed in Table 3 .

Table 3. List of proposed risk management strategies

\begin{tabular}{cll}
\hline Code & \multicolumn{1}{c}{ Risk agent description } & \multicolumn{1}{c}{ Preventive action description } \\
\hline A32 & $\begin{array}{l}\text { The seed production } \\
\text { process was not supervised } \\
\text { by BPSBTPH }\end{array}$ & $\begin{array}{l}\text { Propose training to BPSBTPH } \\
\text { Take part in the certification of potato seed breeder farmers } \\
\text { Apply for potato seed certification }\end{array}$ \\
\hline A28 & Non-certified seeds & $\begin{array}{l}\text { Buy breeder seeds from vegetable crop research center } \\
\text { (Balai Penelitian Tanaman Sayuran-Balitsa) } \\
\text { Buy certified seeds from other breeders }\end{array}$ \\
& &
\end{tabular}

Three preventive actions are proposed to handle priority risk agent. To find out which risk management strategies need to be performed first, an assessment of each PA is needed by considering the ease, such as costs incurred and resources needed, ranking done by correlation assessment and calculation of effectiveness to certification (ETD) for each PA.

The Table 4 shows that the first risk management strategy that is necessary to be carried out by the farmers in Kertasari in terms of potato seed production is to propose training to BPSBTPH. To apply for the training, farmers can submit to the BPSBTPH office. BPSBTPH will process the application and facilitate farmers to participate in the training. The training is important for farmers because through training, they will gain basic knowledge related to the importance of using quality potato seeds, quality potato seed production technology and possible profits from the production of quality potato seeds (Suliansyah et al., 2017). 
Table 4. The ranks of proposed preventive actions

\begin{tabular}{cl}
\hline Rank & \multicolumn{1}{c}{ Preventive action description } \\
\hline 1 & Propose training to BPSBTPH \\
2 & Take part in the certification of potato seed breeder farmers \\
3 & Apply for potato seed certification \\
4 & Buy breeder seeds from vegetable crop research center (Balai Penelitian Tanaman Sayuran- \\
& Balitsa) \\
5 & Buy certified seeds from other breeders \\
\hline
\end{tabular}

After attending the training from BPSBTPH, farmers have to take part in the certification of potato seed breeder farmers. This is important because one of the conditions for farmers who want to apply for potato seed certification is being registered at BPSBTPH (Ministry of Agriculture, 2014). Even though the majority of farmers who produce potato seeds in Kertasari already have certificates, the certificate is no longer valid because of the new regulation of propagation technical and certification of potato seeds. Farmers who want to register to BPSBTPH must fill out the application form and attach a photocopy of the valid National Identity Card. After the submission is made, BPSBTPH will conduct an assessment, field survey and interview.

After having a certificate of competency, farmers can apply for potato seed certification. The certification aims to ensure the purity of the seeds produced, produce high-quality and healthy seeds, facilitate the potato seed consumers to obtain the seeds as expected and provide assurance that the seeds have gone through the inspection stage by labeling the seeds (Suliansyah et al., 2017). Through potato seed certification, various activities carried out by farmers during seed production activities are supervised by BPSBTPH, starting from land preparation to storage in the warehouse.

Through the implementation of the risk management strategy, potato farmers in Kertasari will produce quality and worthy potato seeds. The results of the study by Bacherin (2004) show that farmers in Bandung Regency generally did not practice rouging and sorting, both at the field and in the warehouse, because of their limited skills. By implementing the strategies above, the problem can be minimized because farmers receive guidance and supervision from the BPSBTPH.

Another prevention strategy that can be implemented by farmers to avoid the use of non-certified seeds is by buying breeder seeds from Indonesian Vegetables Research Institute (IVEGRI). The type of seeds that can be purchased at vegetable crop research center are in the form of plantlets. Plantlets are plants produced by in vitro tissue culture. The use of plantlets can also be one of the techniques applied to avoid attacks of diseases caused by viruses. Viruses can survive in potato tubers from one to the next generation (Sugihono and Hasbianto, 2014). According to Priegnitz et al. (2019), farmers who are trained in positive selection to opt for less virus-infected plants and tubers can increase potato production.

In addition to obtaining seed from vegetable crop research center, farmers can buy certified seeds from other breeders. The availability of certified seeds is one of the conditions set by the government for farmers or breeders who want to produce potato seeds. The certification of seeds aims to produce quality-assured seeds and maintain their purity.

\section{CONCLUSIONS}

This research found that the highest severity of impact is rotten harvested potato. The priority risk agent identified is seed production process that is not supervised by the food and horticulture crop seed supervision and certification center, as well as non-certified seeds. The effective handling strategies include proposing training to food and horticulture crop seeds supervision and certification center, taking part in the certification of potato seed breeder farmers, applying for potato seed certification and buying breeder seeds from vegetable crop research center and from other breeders. This research suggests to certify potato seed and renew the competency certification of potato seed breeders.

\section{ACKNOWLEDGEMENT}

The authors would like to thank the farmers for their willingness to take part in this study. 
Moreover, the authors would like to thank the Ministry of Research and Technology of the Republic of Indonesia in 2019 for the financial support for this study, particularly through the scheme of Penelitian Dasar Unggulan Perguruan Tinggi-PDUPT.

\section{REFERENCES}

Abebe, G., \& Alemu, A. (2017). Role of improved seeds towards improving livelihood and food security at Ethiopia. International Journal of Research-Granthaalayah, 5(2), 338-356. https://doi.org/10.29121/granthaala yah.v5.i2.2017.1746

Bacherin, S. (2004). Pengkajian keragaan usahatani dan sistem distribusi bibit kentang di Jawa Barat. Jurnal Pengkajian dan Pengembangan Teknologi Pertanian, 7(2), 125-138. Retrieved from http://ejurnal.litbang .pertanian.go.id/index.php/jpengkajian/article/ view/1506

BPS-Statistics Indonesia. (2019). Production of Vegetables 2019. Retrieved from https:// www.bps.go.id/indicator/55/61/2/productionof-vegetables.html

Burlingame, B., Mouillé, B., \& Charrondiere, R. (2009). Nutrients, bioactive non-nutrients and anti-nutrients in potatoes. Journal of food composition and analysis, 22(6), 494-502. https://doi.org/10.1016/j.jfca.2009.09.001

David, S. (2004). Farmer seed enterprises: a sustainable approach to seed delivery? Agriculture and Human Values, 21(4), 387-397. https://doi.org/10.1007/s10460-004$1247-5$

Dermawan, R. (2006). Pengambilan keputusan landasan filsofis, konsep, dan aplikasi. Bandung: Alfabeta. Retrieved from https:// scholar.google.co.id/scholar?cluster $=1813152$ $2294515890852 \&$ hl=id\&as_sdt=2005\&sciodt $=0,5 \&$ authuser $=3$

Eljai, F., Slamini, M., Mzabri, I., Bekkouch, I., Kouddane, N. E., \& Berrichi, A. (2017). The procedure of seed potato certification in Morocco. Atlas Journal of Biology, 402-406. https://doi.org/10.5147/ajb.v0i0.158

Ezekiel, R., Singh, N., Sharma, S., \& Kaur, A. (2013). Beneficial phytochemicals in potatoa review. Food Research International, 50
(2), 487-496. https://doi.org/10.1016/j.foodres .2011.04.025

Gao, B., Huang, W., Xue, X., Hu, Y., Huang, Y., Wang, L., Ding, S., \& Cui, S. (2019). Comprehensive environmental assessment of potato as staple food policy in China. International journal of environmental research and public health, 16(15), 2700. https://doi.org/10.3390/ijerph16152700

Gunawan, O. S. (2006). Virulensi dan ras Ralstonia solanacearum pada pertanaman kentang di Kecamatan Pangalengan, Kabupaten Bandung, Jawa Barat. Jurnal Hortikultura, 16(3), 211-218. Retrieved from http://ejurnal.litbang.pertanian.go.id/index.ph p/jhort/article/view/1125

Hendra, A., \& Wulandari, E. (2020). Sumber pembiayaan dan produksi benih kentang di Kecamatan Kertasari Kabupaten Bandung. Mimbar Agribisnis: Jurnal Pemikiran Masyarakat Ilmiah Berwawasan Agribisnis, 6(1), 113-119. http://dx.doi.org/10.25157/ma. v6i1.2844

Ilangantileke, S. G., Kadian, M. S., Hossain, M., Hossain, A. E., Jayasinghe, U., \& Mahmood, A. A. (2001). Toward alleviating poverty of rural potato farmers by strengthening the potato seed system in Bangladesh: A rapid rural appraisal. CIP Program Report, 259-264. Retrieved from https://www. researchgate.net/publication/349966173_Tow ard_Alleviating_Poverty_of_Rural_Potato_Fa rmers_by_Strengthening_the_Potato_Seed_S ystem_in_Bangladesh_A_Rapid_Rural_Appr aisal_agro-techniques_for_on-farm_productio n_of_high-quality_seed_Strengtheni

Jella, E. R., Suryanto, A. \& Setyobudi, L. (2017). Dampak aplikasi mulsa dan generasi umbi bibit (G2, G3, Lokal) pada tanaman kentang (Solanum tuberosum Linn). Buana Sains, 17(2), 153-166. https://doi.org/10.33366/bs. v17i2.815

Jufri, A. F., Rahayu, M. S., \& Setiawan, A. (2015). Penanganan penyimpanan kentang bibit (Solanum tuberosum L.) di Bandung. Buletin Agrohorti, 3(1), 65-70. https://doi.org/ 10.29244/agrob.v3i1.14828

King, J. C., \& Slavin, J. L. (2013). White potatoes, human health, and dietary guidance. Advances 
in nutrition: An International Review Journal, 4(3), 393S-401S. https://doi.org/10.3945/an. 112.003525

Kountur, R. (2008). Mudah memahami manajemen risiko perusahaan. Jakarta: PPM. Retrieved from https://scholar.google.com/ scholar?cluster $=9572849988934327766 \&$ hl $=$ en\&oi=scholarr

Kozai, T., Kubota, C., \& Ryoung Jeong, B. (1997). Environmental control for the largescale production of plants through in vitro techniques. Plant Cell, Tissue and Organ Culture, 51, 49-56. https://doi.org/10.1023/ A:1005809518371

Love, S. L., \& Pavek, J. J. (2008). Positioning the potato as a primary food source of vitamin C. American Journal of Potato Research, 85(4), 277-285. https://doi.org/10.1007/s12230-0089030-6

Mansfield, J., Genin, S., Magori, S., Citovsky, V., Sriariyanum, M., Ronald, P., Dow, M., Verdier, V., Beer, S. V., Machado, M. A., Toth, I., Salmond, G., \& Foster, G. D. (2012). Top 10 plant pathogenic bacteria in molecular plant pathology. Molecular Plant Pathology, 13(6), 614-629. https://doi.org/10.1111/j.136 4-3703.2012.00804.x

McGill, C. R., Kurilich, A. C., \& Davignon, J. (2013). The role of potatoes and potato components in cardiometabolic health: A review. Annals of medicine, 45(7), 467473. https://doi.org/10.3109/07853890.2013. 813633

Ministry of Agriculture. (2014). Teknis perbanyakan dan sertifikasi benih kentang. Jakarta: Ministry of Agriculture. Retrieved from https://adoc.pub/teknis-perbanyakan-dan -sertifikasi-benih-kentang.html

Ministry of Agriculture. (2020). Statistik pertanian 2020. Jakarta: Ministry of Agriculture. Retrieved from https://aplikasi2. pertanian.go.id/bdsp/

Mulyono, D., Syah, M. J. A., Sayekti, A. L., \& Hilman, Y. (2017). Kelas benih kentang (Solanum tuberosum L.) berdasarkan pertumbuhan, produksi, dan mutu produk. Jurnal Hortikultura, 27(2), 209-216. http://dx. doi.org/10.21082/jhort.v27n2.2017.p209-216
Musta'inah, A., Hani, E. S. \& Sudarko, S. (2017). Analisis risiko pada usahatani tomat di Kecamatan Ledokombo Kabupaten Jember. Jurnal Agribest, 1(2), 136-151. https://doi. org/10.32528/agribest.v1i2.1153

Muthuraj, R., George, J., \& Ravi, V. (2016). Seed certification standards for quality planting material production of cassava, sweet potato, lesser yam and taro. Journal of Root Crops, 42(1), 3-8. Retrieved from http://www.isrc.in/ ojs/index.php/jrc/article/view/393

Mwaniki, P. K., Wagara, I. N., Birech, R., Kinyua, Z. M., Schulte-Geldermann, E., \& Freyer, B. (2017). Impact of crop rotation sequences on potato in fields inoculated with bacterial wilt caused by Ralstonia solanacearum. African Journal of Agricultural Research, 12(14), 1226-1235. Retrieved from https:// academicjournals.org/journal/AJAR/articlefull-text-pdf/800653463625

Pitojo, S. (2004). Penangkaran benih kentang. Yogyakarta: Kanisius. Retrieved from https:// scholar.google.co.id/scholar?cluster $=7135937$ $431782433457 \&$ hl=id\&as_sdt=2005\&sciodt= $0,5 \&$ authuser $=3$

Priegnitz, U., Lommen, W. J. M., van der Vlugt, R. A. A., \& Struik, P. C. (2019). Impact of positive selection on incidence of different viruses during multiple generations of potato seed tubers in Uganda. Potato Research, 62 (1), 1-30. https://doi.org/10.1007/s11540-0189394-z

Pujawan, I. N., \& Geraldin, L. (2009). House of risk: A model for proactive supply chain risk management. Business Process Management Journal, 15(6), 953-967 https://doi.org/ $10.1108 / 14637150911003801$

Rogi, J. E. X., Kembuan, H. S. G., \& Rombang, J. A. (2016). Laju tumbuh umbi tanaman kentang varietas granola dan supejohn di dataran medium dengan pemulsaan. Jurnal Hortikultura Indonesia, 7(2), 83-90. https:// doi.org/10.29244/jhi.7.2.83-90

Rondon, S. I. (2010). The potato tuberworm: A literature review of its biology, ecology, and control. American Journal of Potato Research, 87, 149-166. https://doi.org/10.1007/s12230009-9123-x 
Roy, B. (2014). Farmers' participatory quality seed production of field crops-A case study. Journal of Crop and Weed, 10(2), 89-93. Retrieved from https://www.cropandweed. com/archives/2014/vol10issue2/16.pdf

Samadi, B. (2007). Kentang dan analisis usaha tani. Yogyakarta: Kanisius. Retrieved from https://scholar.google.co.id/scholar?cluster=1 3976662930651627356\&hl=id\&as_sdt=2005 \&sciodt $=0,5$

Sawicka, B., Mohammed, A., \& Umachandran, K. (2018). Food safety of potato processed in the aspect of acrylamide risk. MOJ Food Process Technol, 6(3), 96-102. https:// doi.org/10.15406/mojfpt.2018.06.00151

Setiawan, A. W. (2019). Epidemiologi penyakit layu bakteri dan perkembangan kompleks spesies Ralstonia solanacearum. Jurnal Galung Tropika, 8(3), 243-270. Retrieved from https://www.jurnalpertanianumpar.com /index.php/jgt/article/view/502

Sharma, K. K., Singh, U. S., Sharma, P., Kumar, A., \& Sharma, L. (2015). Seed treatments for sustainable agriculture-A review. Journal of Applied and Natural Science, 7(1), 521-539. https://doi.org/10.31018/jans.v7i1.641

Sugihono, C. \& Hasbianto, A. (2014). Perkembangan penggunaan teknik kultur jaringan pada tanaman kentang (Solanum tuberosum L.), Prosiding Seminar Nasional Inovasi Teknologi Pertanian Spesifik Lokasi. Banjarbaru. Retrieved from http://kalsel. litbang.pertanian.go.id/ind/images/pdf/semnas 2014/49_cris.pdf

Suliansyah, I., Santosa, H., \& Ekawati. (2017). Pengembangan sentra produksi bibit (penangkaran) kentang bermutu melalui aplikasi teknologi bioseluler di Kabupaten Solok. Jurnal Ilmiah Pengabdian Kepada Masyarakat, 1(2), 106-116. Retrieved from https://www.researchgate.net/publication/331 156201_PENGEMBANGAN_SENTRA_PR
ODUKSI_BIBIT_PENANGKARAN_KENT ANG_BERMUTU_MELALUI_APLIKASI_ TEKNOLOGI_BIOSELULER_DI_KABUPA TEN_SOLOK

Sunaryono, H. (2007). Petunjuk praktis budidaya kentang. Jakarta: Agromedia. Retrieved from https://scholar.google.co.id/scholar?cluster $=6$ $593227186434471026 \& \mathrm{hl}=\mathrm{id} \&$ as_sdt $=2005 \&$ sciodt $=0,5 \&$ authuser $=3$

Tian, J., Chen, J., Ye, X., \& Chen, S. (2016). Health benefits of the potato affected by domestic cooking: A review. Food Chemistry, 202, 165-175. https://doi.org/10.1016/j.food chem.2016.01.120

Widyawati, R. F. (2017). Analisis keterkaitan sektor pertanian dan pengaruhnya terhadap perekonomian Indonesia (analisis input ouput). Jurnal Economia, 13(1), 14-27. https://doi.org/10.47532/jis.v3i2.178

Williams, D. J., Edwards, D., Hamernig, I., Jian, L., James, A. P., Johnson, S. K., \& Tapsell, L. C. (2013). Vegetables containing phytochemicals with potential anti-obesity properties: A review. Food Research International, 52(1), 323-333. https://doi.org/ 10.1016/j.foodres.2013.03.015

Yusianto, R., Marimin, Suprihatin, \& Hardjomidjojo, H. (2020). Spatial analysis for crop land suitability evaluation: A case study of potatoes cultivation in Wonosobo, Indonesia. International Seminar on Application for Technology of Information and Communication (iSemantic), 2020, pp. 313-319. https://doi.org/10.1109/iSemantic50 169.2020.9234284

Zhang, H., Fen, X. U., Yu, W. U., Hu, H. H., \& Dai, X. F. (2017). Progress of potato staple food research and industry development in China. Journal of integrative agriculture, 16(12), 2924-2932. https://doi.org/10.1016/ S2095-3119(17)61736-2 